DOI: $10.23858 / \mathrm{SA} / 73.2021 .1 .2605$

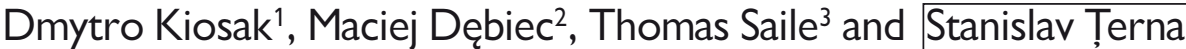

\section{LITHIC INDUSTRY \\ OF TWO LINEARBANDKERAMIK SITES IN MOLDOVA (NICOLAEVCA V AND ȚÂRA II)}

\begin{abstract}
Kiosak D., Dębiec M., Saile T. and Țerna S. 2021. Lithic industry of two Linearbandkeramik sites in Moldova (Nicolaevca V and Țâra II). Sprawozdania Archeologiczne 73/1, 303-329.

The two Linear Pottery culture lithic complexes presented in this paper came from northern Moldova. The Nicolaevca V assemblage was gathered from excavations of a small LBK dwelling, while the Țâra II collection came from an eight-shaped pit. There was a "deposit" of objects suitable for knapping found in Nicolaevca V. This complex reflects flake-oriented expedient knapping. The Țâra II complex represents a complicated sequence for obtaining regular blades. The interpretation of their differences is sought in the social organization of Neolithic flint-knapping, in which the Nicolaevca $V$ lithic assemblage supposedly reflects domestic production in a household context, while Țâra II products could have been involved in the exchange network.
\end{abstract}

Keywords: Neolithic, lithic technology, operative chain approach, caches of objects for knapping Received: 02.02.2021; Revised: 15.03.2021; Accepted: 19.05.2021

${ }^{1}$ I. I. Mechnikov Odessa National University, Dvoryanskaya str., 2, Odessa, 65082, Ukraine; Ca' Foscari University, Dorsoduro, 3246, 30123 Venezia VE, Italy; dkiosak@ukr.net; ORCID: oooo-ooo2-3349-4989 ${ }^{2}$ University Rzeszów, Institute of Archaeology, 10 Moniuszki Street, 35-015 Rzeszów, Poland; debiecmaciej@gmail.com; ORCID: 00oo-0002-8679-6278

${ }^{3}$ Chair of Prehistory and Early History, Institute of History, University of Regensburg, Universitätsstraße 31, 93053 Regensburg, Germany; thomas.saile@ur.de; ORCID: oooo-0003-0834-5567 


\section{INTRODUCTION}

The lithic industry of the Linearbandkeramik (LBK) culture is represented to a large extent by laminar complexes dominated by end-scrapers and retouched blades from a typological point of view. The so-called "sickle inserts" are usually recovered in notable series (Tringham 1968; Kaczanowska 1980; Kozłowski 1989; Allard 2004). On the other hand, there is a fair selection of counterexamples: sites that have peculiar structures of lithic complexes for a variety of (supposed) reasons (Gronenborn 1997, 62-65; Gronenborn 1998; Burnez-Lanotte, Allard 2003; Mateiciucova 2008, 156-162; Allard and Denis 2015; Nikitin et al. 2019). The interpretation of this variability is an important problem to solve.

The easternmost line limiting the extent of the LBK has changed recently. Dmytro Haskevych (Gaskevych) found a new site, Vita-Poshtova, on the Dnieper river, near Kyiv (Gaskevych 1997). In 2011, the Odessa National University survey team found a new site, Kamyane-Zavallia, on the Southern Buh river, thus moving the conventional boundary further to the south-east (Kiosak 2013; Kiosak et al. 2014a; Kiosak et al. 2014b; Saile et al. 2016; Kiosak and Salavert 2018). The notion of a clearly delineated boundary is purely conventional (Nowak 2019, 104-106). The area of settlement in the early Neolithic was not continuous. Rather, it existed in the shape of a number of settled microregions with multiple sites clustered on 10-25 km stretches of land (Lüning 1982). The latter were surrounded by scattered sites of single finds of LBK artefacts in the contexts of indigenous cultures (Nowak 2007; Kiosak 2014; Kitagawa et al. 2018, 203-204). Recent research

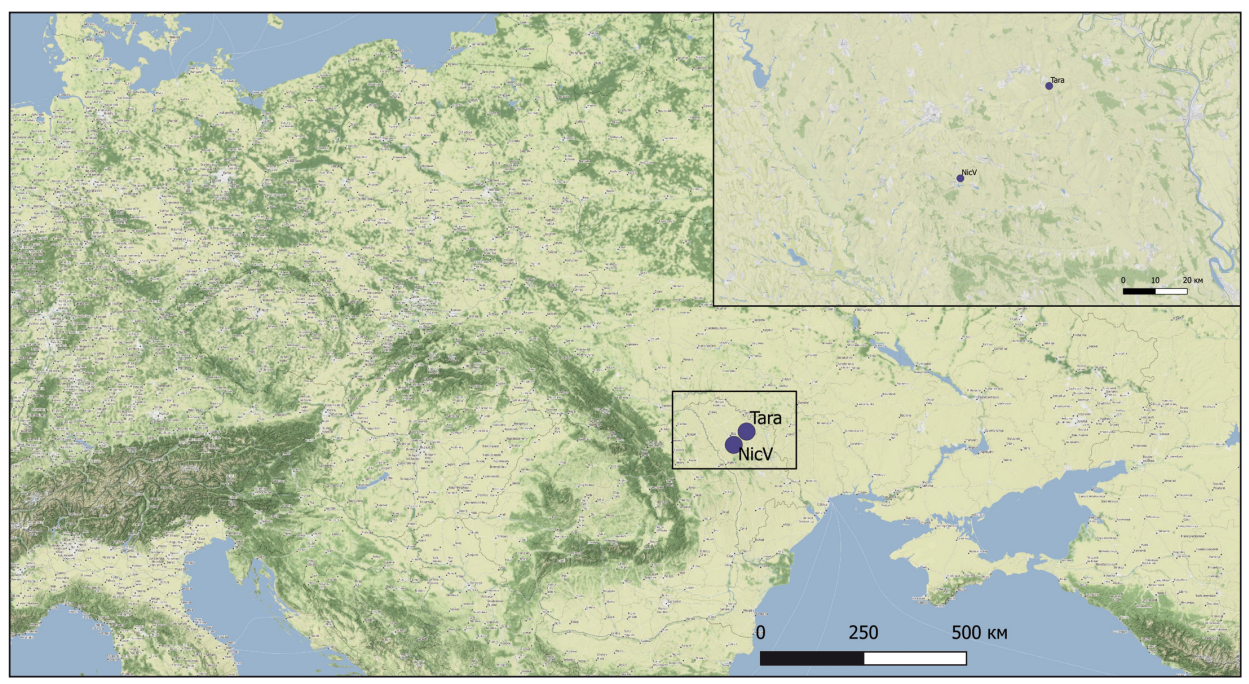

Fig. 1. Location of Nicolaevca V (Nic V) and Țâra II (Tara). Topo: Stamen USA terrain accessed via QGIS 2.18 
suggests that such a microregion existed around the Kamyane-Zavallia site (Kiosak 2017; Kiosak et al. 2020; Saile 2020).

In the marginal areas of the LBK distribution, the development of a Neolithic economy and society is usually placed within the framework of interaction between local foragers and external Neolithic farmers. Lithic artefacts form a category of material culture that is common for groups of both economic types. Thus, the traces of their interaction are often sought in the comparison of lithic complexes. Under such premises, the creativity and ingenuity of the knapping of early farmers is often underestimated, and complexes with a particular structure tend to be interpreted as direct evidence for "Mesolithic influence" (Gronenborn 1998; Mateiciucova 2008, 156-162; Nikitin et al. 2019).

From this point of view, studies on chipped stone assemblages are of particular importance for understanding the settlement at the easternmost fringe of the LBK. The subject of this text is the lithic assemblages of two sites from the territory between the Prut and Dniester rivers (Fig. 1). Both lithic assemblages stand out from the "standard", each in its own way. Interpretation of their peculiarities is far from straightforward.

\section{STATE OF ART}

The lithic industry of the LBK in the eastern part of its distribution has a long history of research. G. Korobkova subjected some LBK collections to use-wear analysis (Korobkova 1987, 165-169). O. Larina produced a synthesis on the typological composition of LBK lithic complexes of modern-day Moldova (Larina 1999, 46-50). The state of research was summed up by Dmytro Haskevych (2003), who defined two variants of the lithic industry. The Volhynian variant is characterized by the prevalence of end-scrapers on blades, retouched blades, "sickle inserts" made on truncated blades, etc. The Middle Dniester variant is characterized by a prevalence of end-scrapers on flakes, often subcircular, and the presence of conical cores and trapezes (Gaskevych 2003). In this paper, we are dealing with the sites of the Middle Dniester variant. Conical cores, geometric microliths and subcircular end-scrapers were treated as "Mesolithic heritage" (Păunescu 1970, 39; Larina 1999, 50; Turcanu 2009, 160; Dergachev and Larina 2015).

\section{RAW MATERIAL}

The raw material available to the early farmers in the south of Eastern Europe was described by V. Petrougne (1995). There are outcrops of so called excellent-quality "Volhynian" flint to the north of the region under study. The northern part of modern-day Moldova contains numerous outcrops of Middle Dniester silicites (Petrougne 1995). These two varieties are the most important for LBK sites of the Prut-Dniester region. 
The flint varieties (lithogroups) were defined by macroscopic analyses on colour, texture, inclusions, cortex, etc., of the available pieces. They were named according to a code proposed by M. Pawlikowski (Pawlikowski 1992). The first component stands for the country of in which the lithogroup was discovered (MD, in our case Moldova), the second denotes the place of discovery (site, outcrop etc., Nic in our case, Nicolaeuca V) and the third indicates the type of raw material used ( $\mathrm{F}$ - flint) and the number of the lithogroup (1-6).

MD-Nic-F1 - grey, dark-grey, with white inclusions, transparent when thin, in small whitish points and with spongy cortex, very cavernous (Petrougne 1971);

MD-Nic-F2 - rather similar to the previous group but with much larger white inclusions, giving a "zonal outlook" to a piece;

MD-Nic-F3 - very dark, with small, white punctuations; non-transparent flint;

MD-Nic-F4 - transparent, dark-grey, with small whitish points; very plastic flint;

MD-Nic-F5 - jelly-like, semi-transparent, plastic, with large white inclusions.

Md-Nic-F7 - very transparent, plastic flint, corresponding to the Turonian ("Volhynan") flints of Western Ukraine (Petrougne 1995).

\section{THE SITES}

The two sites that were selected for this study belong to the "Middle Dniester" variant of the LBK. They are situated in the north of modern-day Moldova. There is a distance of over $40 \mathrm{~km}$ between them (Fig. 1).

Țâra II stands on the bank of the Reut river. It was discovered by V. Marchevici (Markevich) in 1958, and was excavated by T. S. Passek in 1960 (Passek and Chernysh 1963, 29-30). There, in a section of a riverbank, a typical eight-shaped pit was excavated. It contained numerous potsherds with Notenkopf decoration alongside shards of coarseware. Excavators noted an elevated amount of flintknapping debris at the bottom of the pit, near the fireplace that was recovered there.

The site, Nicolaevca V, was discovered by V. Bicbaev in 1973-1976, was surveyed and tested by trenches in 2014-2016, and was excavated in 2019 by an international expedition headed by Stanislav Țerna and Maciej Dębiec (Saile et al. 2016). The remains of a typical LBK house were recovered - a Kleinbau-3-type building (Saile 2020). The site belongs to the Notenkopf phase of the LBK.

\section{NICOLAEVCA V COLLECTION}

Here we discuss the lithic artefacts that were found during the excavations of 2019. The materials from the preliminary surveys were not accessible to the authors, but are known to us from publication (Larina and Dergachev 2017, 185-187). 
Table 1. General summary of the technological categories of the assemblage from Nicolaevca $V$

\begin{tabular}{|c|l|c|c|}
\hline No. & \multicolumn{1}{|c|}{ Group } & Quantity & Percentage \% \\
\hline 1 & Pebble & 1 & 0.43 \\
\hline 2 & Pre-core & 2 & 0.86 \\
\hline 3 & Core-like chunk & 1 & 0.43 \\
\hline 4 & Hammerstone & 5 & 2.15 \\
\hline 5 & "Retoucher" & 1 & 0.43 \\
\hline 6 & Core & 19 & 8.15 \\
\hline 7 & Flake & 105 & 45.06 \\
\hline 8 & Chunk & 8 & 3.43 \\
\hline 9 & Blade & 24 & 10.30 \\
\hline 10 & Primary and subprimary flakes & 11 & 4.72 \\
\hline 11 & Technical flake & 12 & 5.15 \\
\hline 12 & Flake from hammerstone & 1 & 0.43 \\
\hline 13 & Tools & 43 & 18.45 \\
\hline 14 & Total & 233 & 100.00 \\
\hline
\end{tabular}

The presented collection consists of two different groups of objects. Pieces of the first group were gathered in the course of excavations of the dwelling structure (long house) in the excavation pit with a size of $514 \mathrm{~m}^{2}$, while the second group is composed of items coming from a concentrated scatter of finds (deposit?), mostly of chipped stone on the surface of a $1 \times 1 \mathrm{~m}^{2}$ area, which lay in a long pit, just outside the house.

The first group is representative of the lithic technology of the Nicolaevca V site "in general", and the second group reflects a particular episode of flint-working. They will be described separately in the following text.

Summary of assemblage. Assemblage I consists of 22 pieces of knapping $(9.44 \%$, groups 1-3, 6 from Table 1), 6 "tools for knapping” (2.58\%, groups 4-5), 23 technical and primary flakes (9.87\%, groups 10-12), 129 unmodified products of debitage $(55.36 \%$, groups 7-9) and 43 items with modified shape, either by retouching or trimming or burin blows, or by macrotraces of use (“tools”, 18.45\%, group 13).

Objects of knapping are represented by a tested pebble ( 1 item), two pre-cores, a corelike chunk, and 19 cores. The tested pebble has an alluvial cortex. Several detachments were taken off it, and it was later rolled by water flow again in such a way that detachments were covered by secondary cortex. It is $70.5 \mathrm{~mm}$ long and $59 \mathrm{~mm}$ wide, with a weight of $217 \mathrm{gr}$. It is quite suitable for future knapping and maybe represents an object taken to the site in anticipation of future needs.

The core-like chunk is a fragment of a core that was very cavernous. After the inhomogeneity of the raw material had stopped the knapping, several flakes were still detached. 

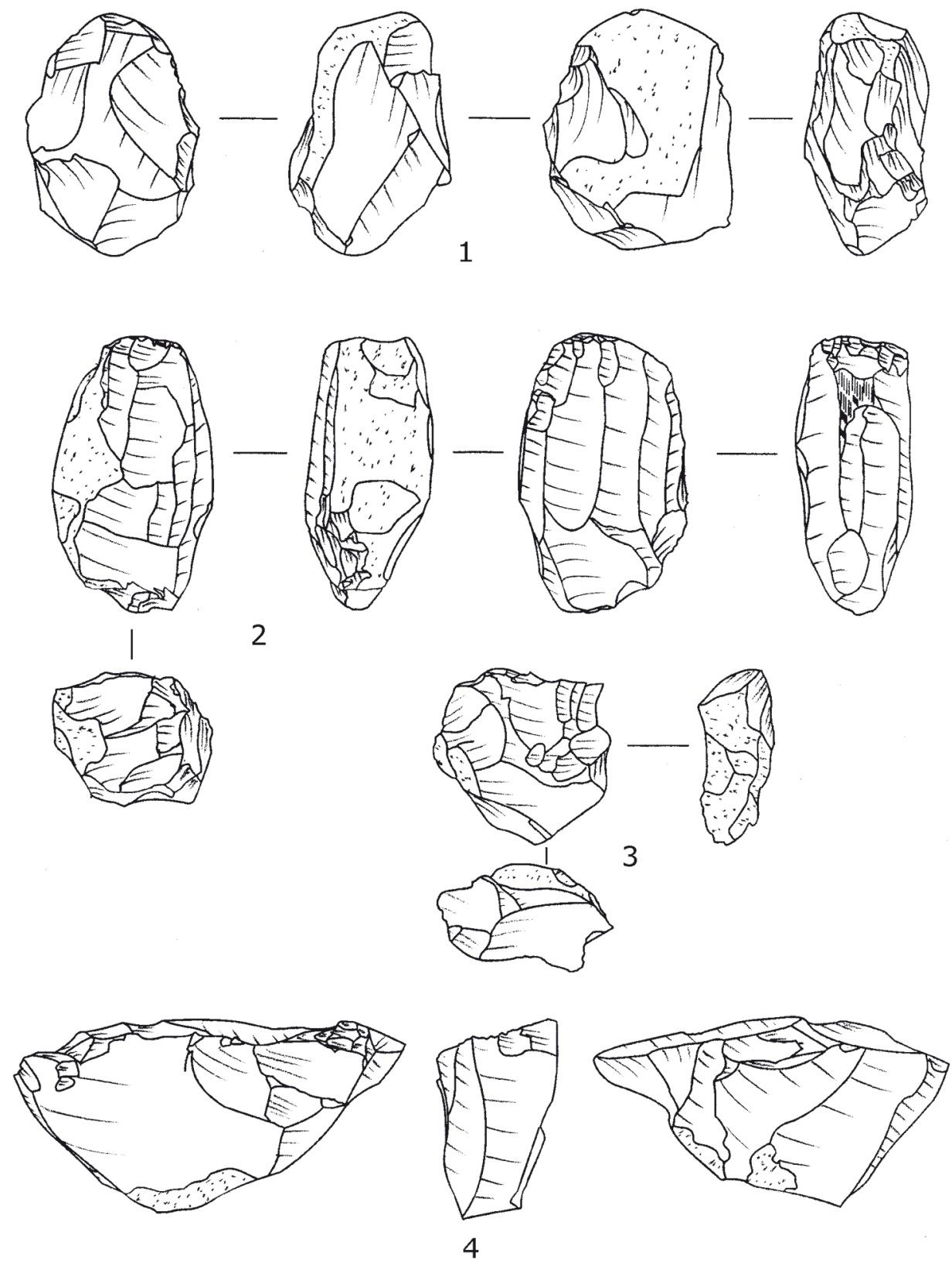

IIII - smoothed surface

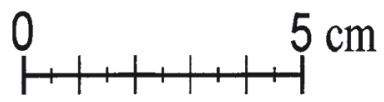

Fig. 2. Nicolaevca V. Cores (1-4).

Drawing conventions: circle - point of impact, filled - with a bulb preserved, dotted line - breakage 
Pre-cores are generally smaller than cores, so they actually do not represent the earlier stages of the operative chain that resulted in the shaping of most available cores. The precore (Fig. 2: 1) is in fact a pebble with the remains of a working surface on one side and with a crest formed on the other side. Thus, the core was exploited for a while, and later, an attempt to open a new working surface was made. The crest was formed by a sequence of alternating detachments forming the sides by using the notch of the bulb of a previous removal as a point of impact for the next. A similar crest was shaped along the complete perimeter of a chunk (another pre-core), also probably in an attempt to re-use a piece that was already knapped.

Cores were used mostly for the detachment of flakes (10 pcs), flakes and blades (3 pcs) and blades (6 pcs). The cores for flakes are amorphous (4 pcs) or subprismatic (4 pcs). There are also a prismatic core and a radial core for flakes. The detachments of flakes were rarely prepared, which was mostly limited to the trimming of overhang (Fig. 2: 3). Striking platforms are flat and unmodified. They often bear ring-cracks indicating quite rough impact in order to detach flakes. Cores for flakes had one platform (7 pcs) or two platforms (2 pcs). The radial core has a radial striking platform along its perimeter. In many cases, the knapping occurred on the suitable angle of the flint piece.

Some cores were used for the production of both blades and flakes. Usually flakes and blades were detached from different working surfaces. Such cores (3 pcs.) are amorphous, subprismatic and prismatic. Their products have curved edges and an irregular dorsal pattern of negatives.

Cores for laminar production were prismatic (3 pcs) and subprismatic ( 3 pcs). Only one core was used for the removal of microblades and bladelets - a very small $(30 \times 30 \mathrm{~mm}$, 15 gr) exhausted core, belonging to the so-called "flat" core type (Telegin 1976).

Cores for blades have complex striking platforms with a history of repair and correction reflected in the negatives of rejuvenation flakes. These cores had either two striking platforms (3 pcs) or a single striking platform preserved ( $3 \mathrm{pcs}$ ). The fronts of laminar detachments are relatively short and narrow; often, they are flanks of knapped objects (Fig. 2: 4). Neo-crests (Marchand 1999) were formed in order to widen working surfaces, but sometimes without success. A broken core for regular blades was re-oriented and reused for laminar detachment without much preparation - not even the removal of an overhang. The resulting blades were short and irregular. It seems the complex sequences of blade-core preparation were not used by Nicolaevca knappers. The cores were used to detach flakes and short, irregular blades and bladelets in opportunistic way. The only core designed for a prolonged, serial laminar production (Fig. 2: 2) is a prismatic core with a single striking platform and a working surface along $3 / 4$ of its perimeter. Its back and keel were shaped with a double-sided crest. It is $58 \times 34 \mathrm{~mm}$ and weighs 66 gr. It could be considered an outlier in a rather flake-oriented industry.

The tools for knapping include 5 spherical hammerstones. Some are evidently re-used cores covered with starry surfaces from multiple hits, as a result of which their shape 
became subspherical. Their weights range from 73 to 188 gr, indicating probable differences in functional application. There is also one "retoucher", which is an elongated object shaped by 3 double-sided crests. The crests give it a sub-cylindrical shape. Its edges and ends bear traces of multiple hits. Similar items were also labelled as "retouchers" (Markevich 1974, 85); however, definite evidence for their function is still missing.

Primary and subprimary flakes are made of raw materials that are indicative of local origin. Their percentage is typical for a situation in which the decortification itself took place elsewhere and the knapping of the tested nodules occurred on-site. Some cortex was removed on site, but only rarely were the resulting cortex-bearing flakes the first flakes detached from a given piece of raw material. Thus, the raw material was imported to the site in the shape of tested nodules and/or prepared pre-cores and cores.

Technical flakes included edge removals (elongated flakes of triangular cross-section, 6 pcs), crested flakes (3 pcs), two flakes of re-orientation and a crested blade. They are connected with the renovation of short and narrow working surfaces, the reorientation of cores after a primary working surface was exhausted and the widening of a working surface to new sides of a core. The short, crested detachments (rather flakes than blades) may in fact be related to similar operations and, thus, should be treated as neo-crested flakes elements of core utilization and not the initial detachments of serial production. The absence of rejuvenation flakes of cores is very diagnostic. It seems that cores were prepared elsewhere and there was utilization of pre-prepared cores on site, mostly limited by the small size of the cores and multiple cavities in the original pieces of raw material, which resulted in numerous attempts at core reorientation and shifting of working surfaces in order to finalize the already quite exhausted cores.

The composition of Debitage products at the site is very interesting. Flakes are more than four times as common as blades when we compare unmodified blanks. Façonnage touched blades and flakes are in almost equal proportions; however, some retouched blades are too regular to have been produced by the simple techniques in use on the site. They could have been brought from elsewhere. Thus, the Nicolaevca V industry was flakeoriented. Almost 3/4 of the flakes had lengths between $10-30 \mathrm{~mm}$, and about one quarter were between 30-50 mm (Table 2). Smaller and larger flakes are very rare. Large flakes were probably impossible to obtain due to the small size of the raw material pieces (pebbles

Table 2. Flakes. Metrics

\begin{tabular}{|c|c|c|c|}
\hline No. & Metric group (length) & Quantity & Percentage \% \\
\hline 1 & $0-10 \mathrm{~mm}$ & 2 & 1.90 \\
\hline 2 & $10-30 \mathrm{~mm}$ & 74 & 70.48 \\
\hline 3 & $30-50 \mathrm{~mm}$ & 26 & 24.76 \\
\hline 4 & over $50 \mathrm{~mm}$ & 3 & 2.86 \\
\hline 5 & Total & 105 & 100.00 \\
\hline
\end{tabular}


Table 3. Blades. Metrics

\begin{tabular}{|c|c|c|c|c|c|}
\hline Metrical group (width) & Distal & Medial & Proximal & Complete & Total \\
\hline $0-7 \mathrm{~mm}$ & 0 & 0 & 0 & 0 & 0 \\
\hline $7-12 \mathrm{~mm}$ & 1 & 1 & 2 & 0 & 4 \\
\hline $12-20 \mathrm{~mm}$ & 4 & 3 & 7 & 2 & 16 \\
\hline over $20 \mathrm{~mm}$ & 0 & 0 & 3 & 1 & 4 \\
\hline Total & 5 & 4 & 12 & 3 & 24 \\
\hline
\end{tabular}

and nodules). Absence of smaller flakes, which are omnipresent indicators of on-site knapping, points to major knapping efforts taking place elsewhere, outside the excavated area. However, the location of knapping was likely not too far from the excavated "long" house, because the multiplicity of flakes and other by-products of knapping, which are usually useless to transport, would indicate that these products were widely available for expedient use in the Nicolaevca V household (Saile 2020).

Flakes often exhibit cortex or parts of cavities and other inhomogeneities that were exposed by their detachment. It seems that cavities were often an obstacle for better knapping.

Blades usually are fragmented (Table 3). Complete blades are very unusual. Fragmentation often occurred just by removing the curved distal part, so proximal "long" fragments (Fig. 3: 5) dominate the assemblage. Rarely does the length of a blade surpass $40 \mathrm{~mm}$. Regular, laminar products with parallel edges and dorsal ridges were exceptionally rare (Fig. 3: 7).

Modified items ("tools", Table 4) are made on flakes (22 pcs), blades (18 pcs), and technical flakes (2 pcs), and a chunk was retouched as well.

End-scrapers form the most numerous group (35\%). They are mostly done on flakes (4/5). The front ends of scrapers were shaped on ends of blades with removed bulbs ("shortened"; Stanko 1982; 3 pcs) and flakes (5 items, Fig. 3: 12, 13, 16, 17). The front ends of scrapers were also widened on sides of flakes, sometimes even forming subcircular tools (2 pcs, Fig. $3: 11 ; 18$ ). In a single case, an end-scraper with a rounded front was formed on a side of a flake (Fig. 3: 15). There is also a single side-scraper. Retouched blades include a fragment with two sides bearing semi-abrupt retouch and 4 pieces with marginal, simple, partial retouch (Fig. 3: 2, 6). Five blades bear characteristic angular polish - so called "sickle gloss" (Fig. 3: 8-9); in three cases, this is accompanied by retouch on the sides. Flakes and blades were truncated by abrupt retouch. A single flake bears both a truncated end and an abruptly retouched side (Fig. 3: 4). Encoches were retouched on a flake and on a subcrested blade (Fig. 3: 3). Some items bear irregular retouch (flakes, a chunk, and an edge flake). There is a straight perforator on a blade, formed by abrupt retouch along two sides (Fig. 3: 10). This is definitely a Neolithic element, absent in Mesolithic collections of the region (Telegin 1976). A fire-striker is a flake with multiple ring-cracks on 

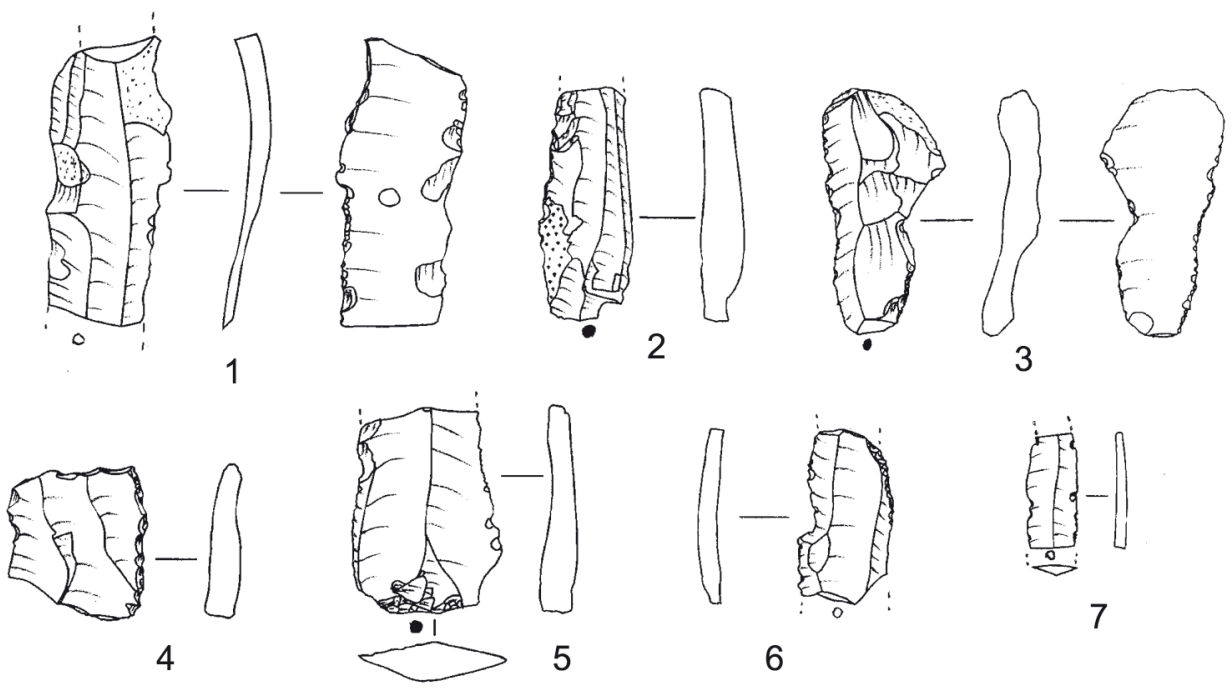

5

6

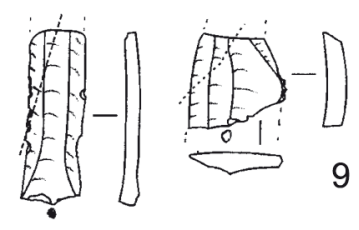

8

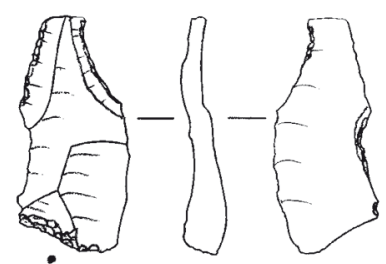
10

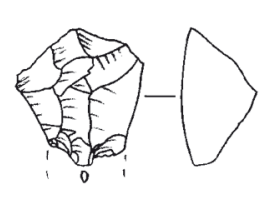

12

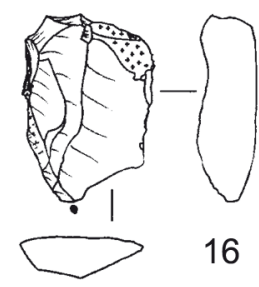

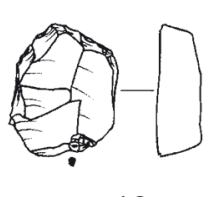

13
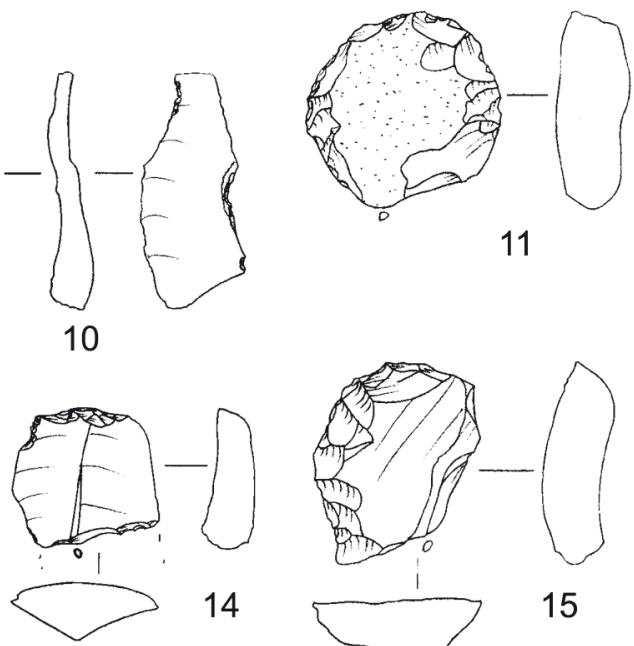

11

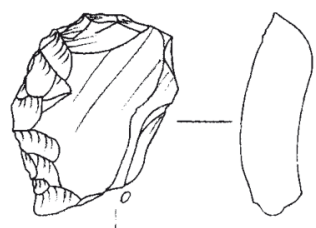

15
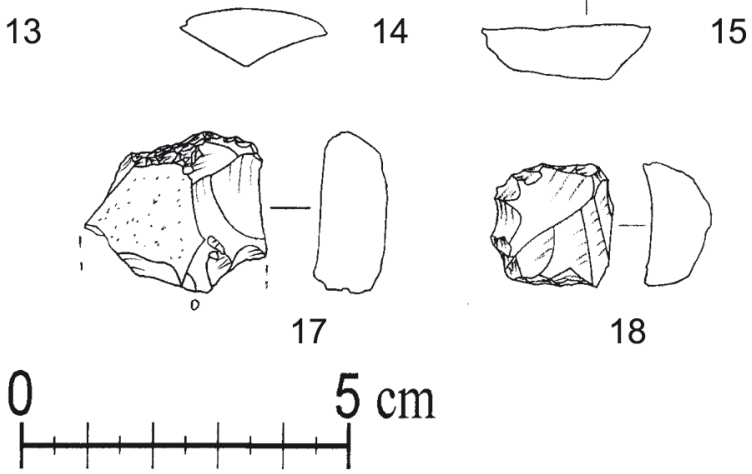

Fig. 3. Nicolaevca V. Tools (1-18) 
Table 4. Tools and worked pieces

\begin{tabular}{|c|c|c|c|}
\hline No. & Type & Quantity & Percentage $\%$ \\
\hline \multirow{7}{*}{1} & End-scrapers & 15 & 34.88 \\
\hline & on shortened blade & 3 & 6.98 \\
\hline & on flake & 5 & 11.63 \\
\hline & on side of flake & 1 & 2.33 \\
\hline & subcircular & 2 & 4.65 \\
\hline & on end and side of flake & 2 & 4.65 \\
\hline & front of scraper & 2 & 4.65 \\
\hline 2 & Side-scraper & 1 & 2.33 \\
\hline 3 & Blade with polish and retouch & 5 & 11.63 \\
\hline 4 & Truncated flake & 2 & 4.65 \\
\hline 5 & Truncated blade & 3 & 6.98 \\
\hline \multirow{3}{*}{6} & Blade with retouch & 5 & 11.63 \\
\hline & semi-abrupt on 2 sides & 1 & 2.33 \\
\hline & marginal simple & 4 & 9.30 \\
\hline 7 & Edge flake with retouch & 1 & 2.33 \\
\hline 8 & Retouched flake & 4 & 9.30 \\
\hline 9 & Multiple transversal burin on a blade & 1 & 2.33 \\
\hline 10 & Perforator on blade & 1 & 2.33 \\
\hline \multirow{3}{*}{11} & Encoches & 2 & 4.65 \\
\hline & on flake & 1 & 2.33 \\
\hline & on subcrested blade & 1 & 2.33 \\
\hline 12 & Fire-striker & 1 & 2.33 \\
\hline 13 & Piece ecaille & 1 & 2.33 \\
\hline 14 & Retouched chunk & 1 & 2.33 \\
\hline 15 & Total & 43 & 100.00 \\
\hline
\end{tabular}

its ventral surface, opposite to multiple facets of repeated detachments. A multiple transversal burin was made on a blade. The burin blows were delivered from the side of the blade, along the surface of breakage, when fragmenting the blade. Burins are few in LBK collections from Moldova (Larina 1999, 46-50), but are rather numerous in Volhynia (Manko and Telizhenko 2016).

\section{"Deposit"}

A dense scatter (object 3008) of lithic finds was comprised of 32 chipped flint pieces and 1 sandstone plate $(61 \times 42 \mathrm{~mm})$. Similar artefacts were called "pallets" by V. I. Marchevici. The chipped stone assemblage consisted of a hammerstone, four pre-cores, two core-like chunks, three thick flakes, a subprimary flake, a blade and 20 cores. 

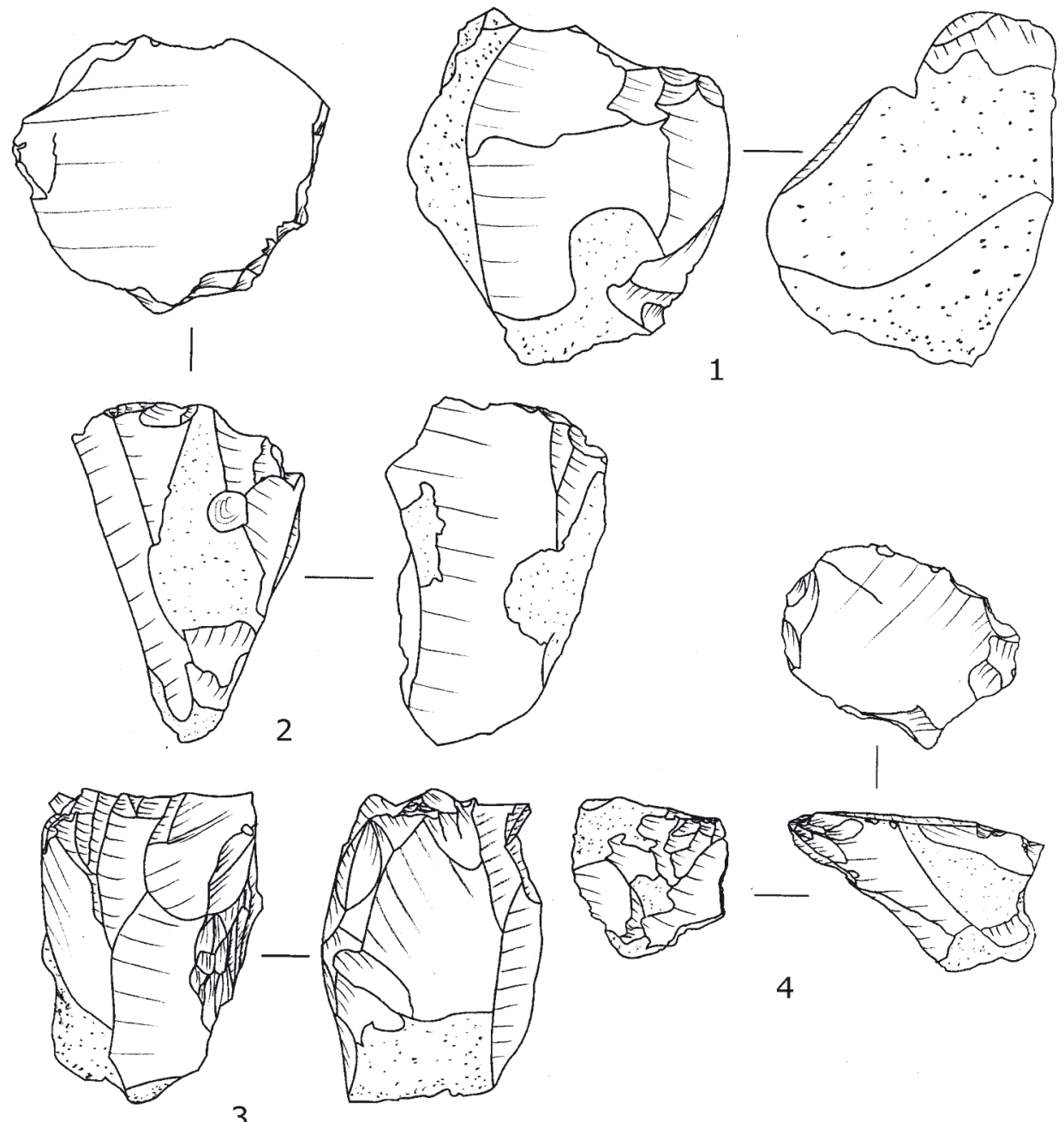

3
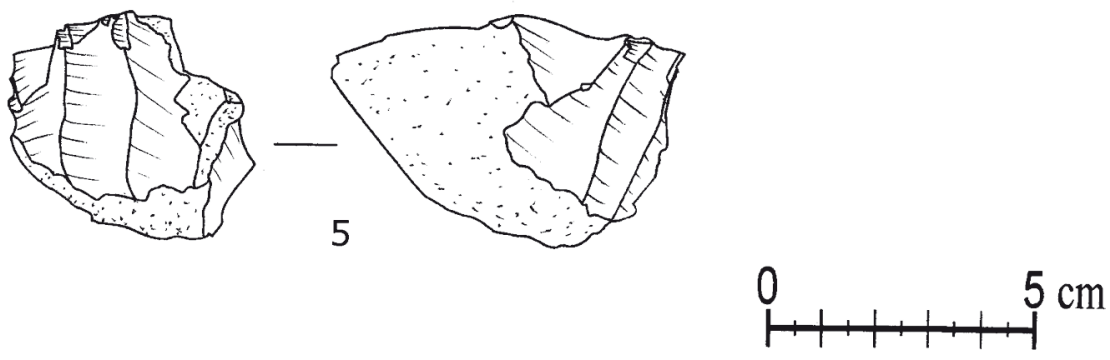

Fig. 4. Nicolaevca V. Cores from "deposit" (1-5) 
The hammerstone (Fig. 6: 6) is spherical with a diameter of $44 \mathrm{~mm}$ and a weight of 110 gr. It is made of flint, and in fact represents a re-used core.

Pre-cores are variable. One pre-core (Fig. 6: 2) is semi-naviform. A wide platform was shaped by a single blow. The flank was prepared by a row of wide trapezoidal flakes. An attempt to create a keel failed due to the inhomogeneity revealed by small detachments from another flank. Still, it could have been useful for flake production. Another pre-core (Fig. 5: 4) had a double-sided crest formed on its narrow face. After an attempt to remove it, the object was left unmodified. Nonetheless, it retained enough volume to continue knapping (163 gr). A third pre-core is of naviform shape (Fig. 5: 2). It had a crest formed by convergent flake removal and, further down, by typical double-sided preparation. The crest was not removed, probably in anticipation of further knapping. The last pre-core is too small for further serial production. It is encompassed by a double-sided crest. Probably, it was prepared to be re-used as a hammer, and the crest was needed as an accommodative element.

Cores were mostly used for flake production (13 pcs, Fig. 4: 1; Fig. 5: 3). They each had a single striking platform, along with a secondary core where a second platform was situated in order to exploit the second narrow face of a thick flake. Flake cores are wedgelike (1 pcs, Fig. 4: 2), prismatic (6 pcs), narrow-faced (1 pcs) or narrow-faced on the sides of thick flakes (secondary, 4 pcs). These categories are arbitrary so far as in almost every case, a suitable front was knapped for a series of flakes that were removed without much preparation. Sometimes such a front was found along the wider side of a core and quite often along the narrow side (Fig. 4: 4, 5), but in particular along the edges of thick flakes. The secondary core (Fig. 6: 3) had some flakes removed off its ventral surface, making it technically a Kombewa core (Inizian et al. 1995). The cores are less exhausted than cores found in the excavation pit in general. They have fewer platforms, fewer working surfaces and fewer traces of re-orientation. In most cases, it seems that a single series of flakes was removed before objects were deposited in scatter 3008 .

Three cores were used for both blade and flake production. Usually, they are subprismatic and have two striking platforms and working surfaces, each for a separate type of product (Fig. 4: 3). Sometimes, in course of mostly flake production, some products were obtained that were long enough to be treated as short, irregular blades.

Four cores were utilized in the course of blade production. In two cases, thick flakes were used as cores. The edges of the flakes were used as narrow faces to detach a series of curved, short blades. Small alluvial pebbles (up to $90 \mathrm{~mm}$ long) were used to remove laminar products from one of the sides (Fig. 5: 1). Striking platforms of blade cores bear traces of preparation by flaking, and sometimes even abrasion.

Most cores did not show hinges or other visible obstacles for further knapping. They were suitable for the continuation of serial detachments, and due to their weight, they retained some useful volume.

Core-like chunks have some traces of knapping, h but there was no evidence of repetitive, serial use. They are suitable for further utilization. 

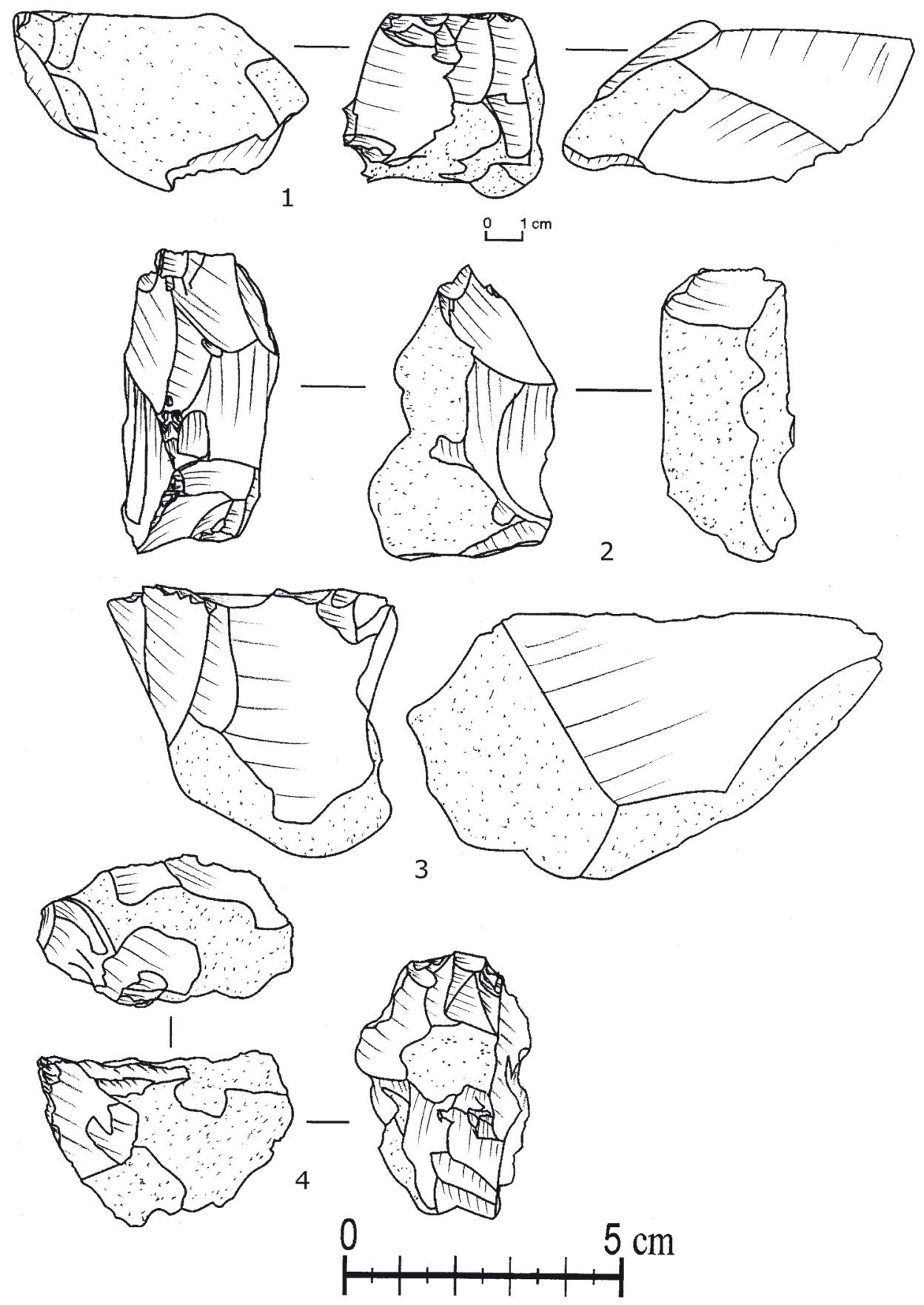

Fig. 5. Nicolaevca V. Cores from "deposit” (1-4) 
Debitage products are mostly intended for re-use as secondary cores. Flakes are thick $(17-33 \mathrm{~mm})$ and resemble other flakes that were used as secondary cores in the assemblage. There is one technical flake in the assemblage: a wide, trapezoidal flake, formed in course of flanks formation. It has a shape and dimensions that made it a suitable blank for a retouched tool. The only blade is clearly an aim product of reduction. It is a long, proximal part, $45 \times 14 \mathrm{~mm}$, with a concave, prepared butt.
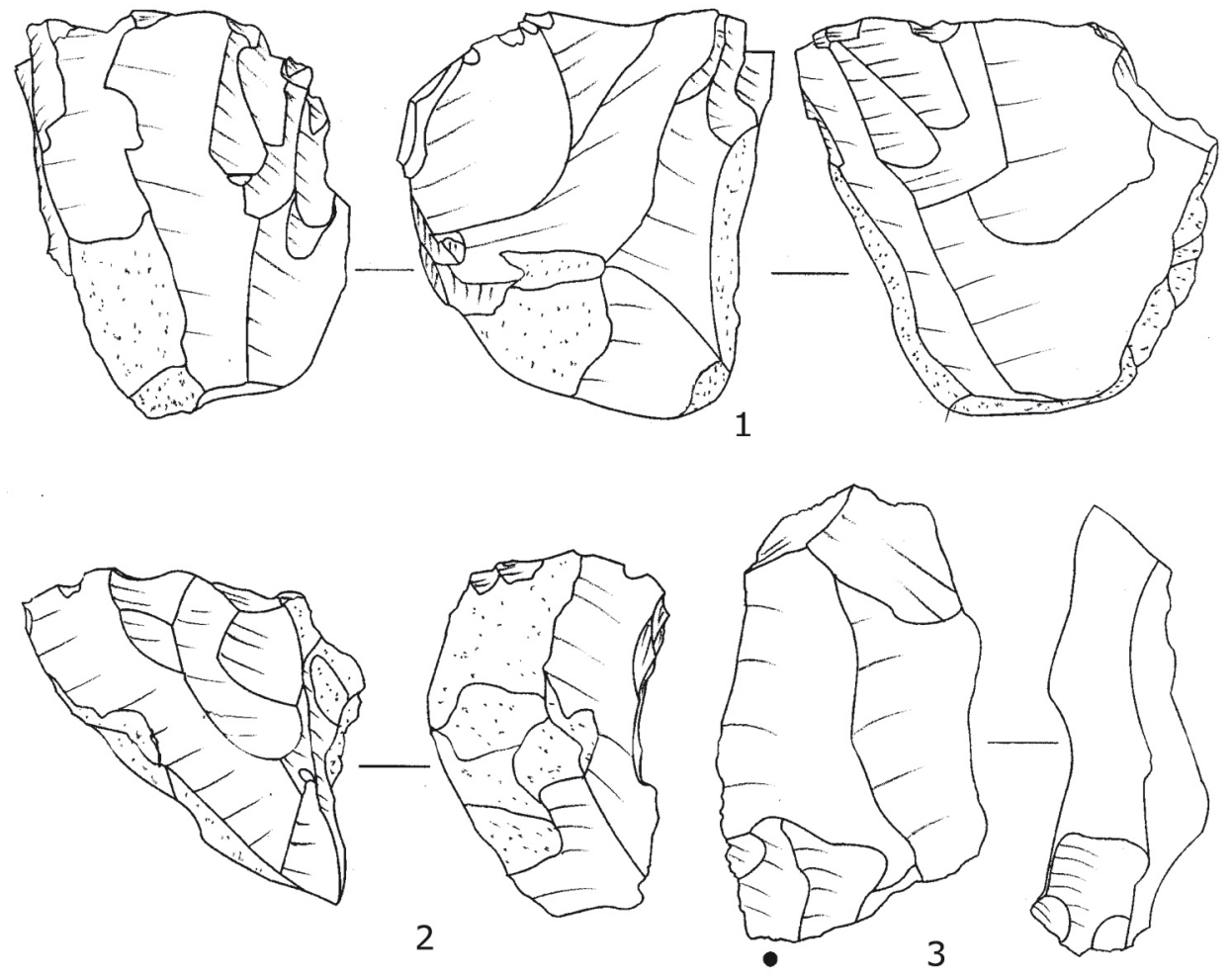

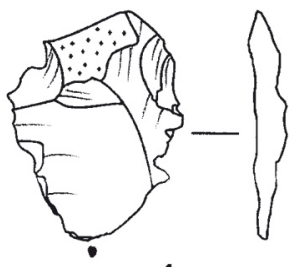

4

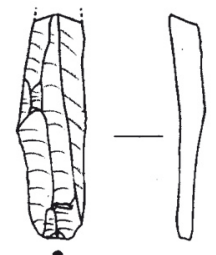

5

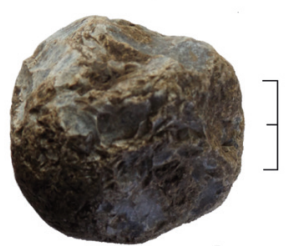

6

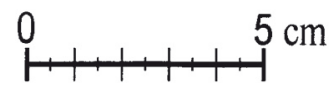

Fig. 6. Nicolaevca V. Objects from "deposit" (1-6) 
Thus, the lithic assemblage of Nicolaevca V Kleinbau represents simple, opportunistic knapping in pursuit of flakes or short, irregular blades. Preparation for detachment is rare and uneven. The laminar component of the complex is confined to a few items. Regular serial production of blades was limited, if indeed it ever existed on the site.

\section{Țâra II collection}

The chipped stone assemblage consisted of 180 pieces from Țâra II. We were able to study 121 artefacts kept in the Odessa Archaeological Museum of the Ukrainian NAS. Over 40 finds are kept in Chişinau, in the National Historical Museum of Moldova. They were published by V. Dergachev and O. Larina (2017). Descriptions of the finds, made by the excavators, seem to imply that the collection from the pit is kept in Odessa, while other miscellaneous lithic finds are in Chişinau.

Assemblage consists of 21 pieces of knapping (17.36\%), 4 fragments of "tools for knapping" (3.31\%), 21 pieces of technical and primary flakes (17.35\%), 39 pieces of unmodified products of debitage (32.23\%) and 21 pieces with shapes modified either by retouch, trimming, burin blows, or by macrotraces of use ("tools", 17.36\%).

The collection includes numerous pebbles and fragments thereof (11 pcs, 9.09\%). They represent lithogroups MD-Nic-F1 - F3. Outcrops of similar flint are known in close vicinity of the site. The bottom of Reut river is sometimes paved with flint pebbles of similar quality (Larina 1999). Some pebbles from Țâra II weigh about $1 \mathrm{~kg}$, retaining a large mass of raw material. A single core re-used as a hammerstone still had cortex portions preserved in such a way that we can reconstruct the general dimensions of the pebble. It was an oval,

Table 5. General summary of the technological categories of the assemblage from Țâra II

\begin{tabular}{|c|l|c|c|}
\hline No. & \multicolumn{1}{|c|}{ Group } & Quantity & Percentage \% \\
\hline 1 & Pebbles flaked and unflaked & 11 & 9.09 \\
\hline 2 & Chunks & 4 & 3.31 \\
\hline 3 & Pre-cores & 2 & 1.65 \\
\hline 4 & Expedient cores & 10 & 8.26 \\
\hline 5 & Cores & 9 & 7.44 \\
\hline 6 & Primary and subprimary flakes & 13 & 10.74 \\
\hline 7 & Technical flakes & 8 & 6.61 \\
\hline 8 & Flakes & 24 & 19.83 \\
\hline 9 & Blades & 15 & 12.40 \\
\hline 10 & Hammerstones & 4 & 3.31 \\
\hline 11 & Tools & 21 & 17.36 \\
\hline 12 & Total & 121 & 100.00 \\
\hline
\end{tabular}



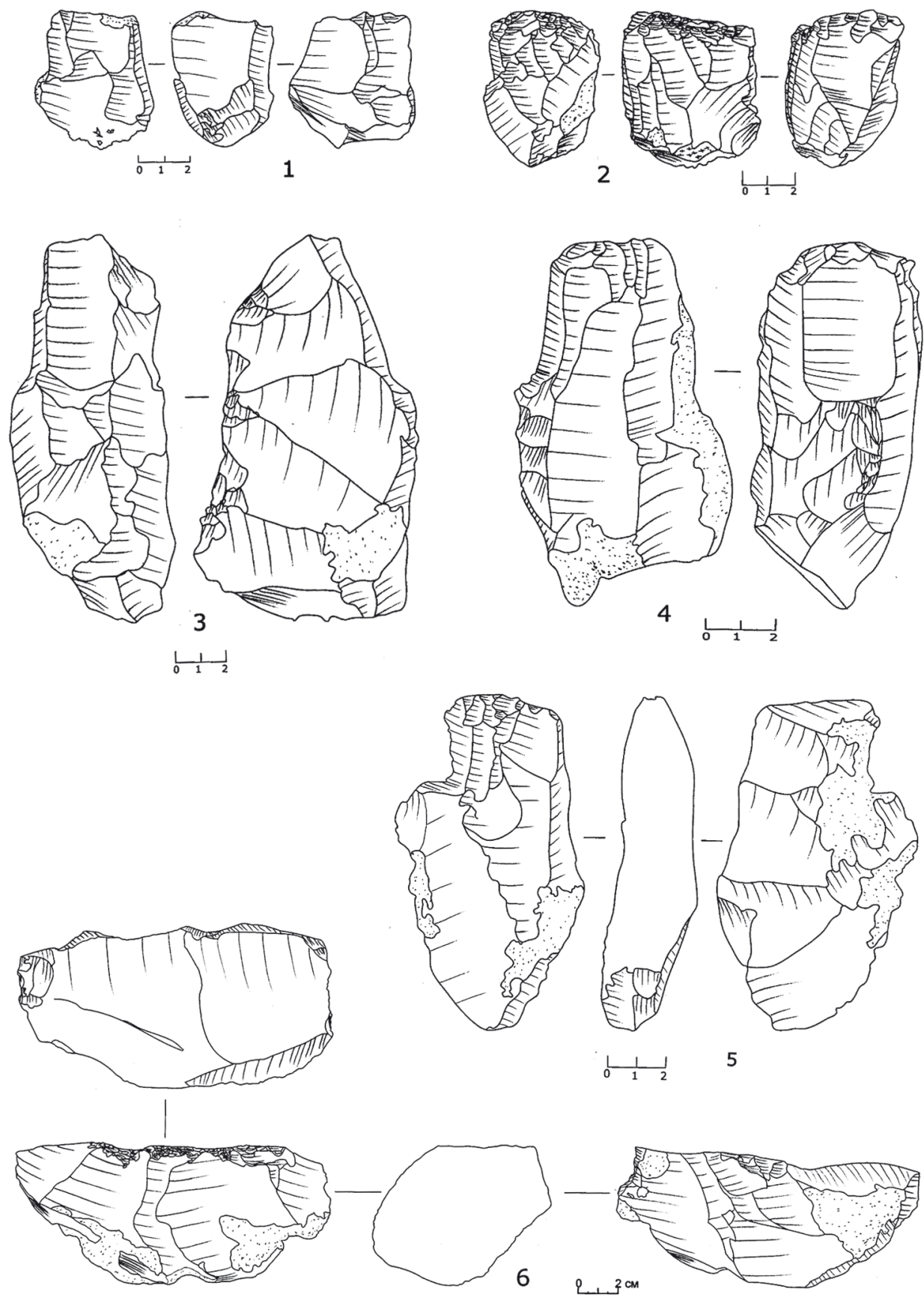

Fig. 7. Țâra II. Pre-core and cores (1-6) 
flattened pebble, $40 \times 40 \mathrm{~mm}$ in section, with a length of $80 \mathrm{~mm}$ at least. T.S. Passek mentions a single core made of "chalk dark flint" (Passek and Chernysh 1963, 30). However, it was absent in the studied selection.

Most cores are expedient (10 pcs). Flakes were struck from a suitable surface without a preparatory effort. Eight expedient cores each have a single striking platform. A core with two opposed platforms was knapped in order to produce short microblades. Another core has three platforms. It was initially made for regular laminar production. It was then reoriented in an effort to strike two series of short, irregular bladelets off the core.

Regular laminar production is represented by items discarded at various stages. There are two typical pre-cores in the collection (Fig. 7: 6), which have a naviform shape. A series of wide, trapezoid detachments were removed on both sides of one of the pre-cores. Striking platforms have angles of 60-75 degrees. Both pre-cores have a weight of 500-550 grams.

Further knapping proceeded in the following way: a crest was knapped off the pre-core. The narrow working surface was opened on a flank of the pre-core. The second striking platform of a pre-core was not used systematically. The knapping proceeded in a unidirectional manner. Cores looked like flank prismatic cores (Fig. 7: 3). Then, when the flank was flattened, an attempt was made to transfer knapping to another side (Fig. 7: 4). A semicrest was formed by detachments off the working surface on a planned side, and then this néo-crête (Marchand 1999) was removed. In at least one case (Fig. 7: 4), this attempt failed. This process, when successful, resulted in a core with a conical or subconical shape. Usually, after finishing serial laminar production, a core was finalised by a series of lamellar removals, or more often by irregular knapping in pursuit of flakes.

Technical flakes (8 pcs, Fig. 8) include rejuvenation flakes from striking platforms (4 pcs), a half-crested blade, re-orientation flakes and a flake from the keel of a sub-conical core. They reflect basically the same technological sequence, as described above - proceeding from a naviform pre-core, knapping flakes off a unidirectional core with two platforms, then widening the working surface to its flanks, and re-shaping it into a prismatic or subconical core with negatives of regular detachments around most of its perimeter.

The collection contains only 15 blades (8\%) and only 24 flakes (19.83\%).

Flakes are generally larger than those from Nicolaevca $V$, and larger items are more numerous (Table 6). This pattern is difficult to find in the remains of knapping in situ. This suggests a selection of pieces for discard into the pit of Țâra II.

Metrical parameters of blades differ from the picture typically seen on residential settlements of the LBK (Table 7). Complete specimens form $1 / 3$ of the selection. Surprisingly, blades are mostly represented by complete, irregular specimens or distal portions. Taking into account the regular laminar patterns of negatives on working surfaces of cores, we would expect the removal of blades from the collection in prehistory.

Retouched tools include eight end-scrapers, two side-scrapers, three fragments of flakes with marginal retouch, two perforators on flakes, two blades with marginal retouch and a blade with oblique truncation (Table 8). 

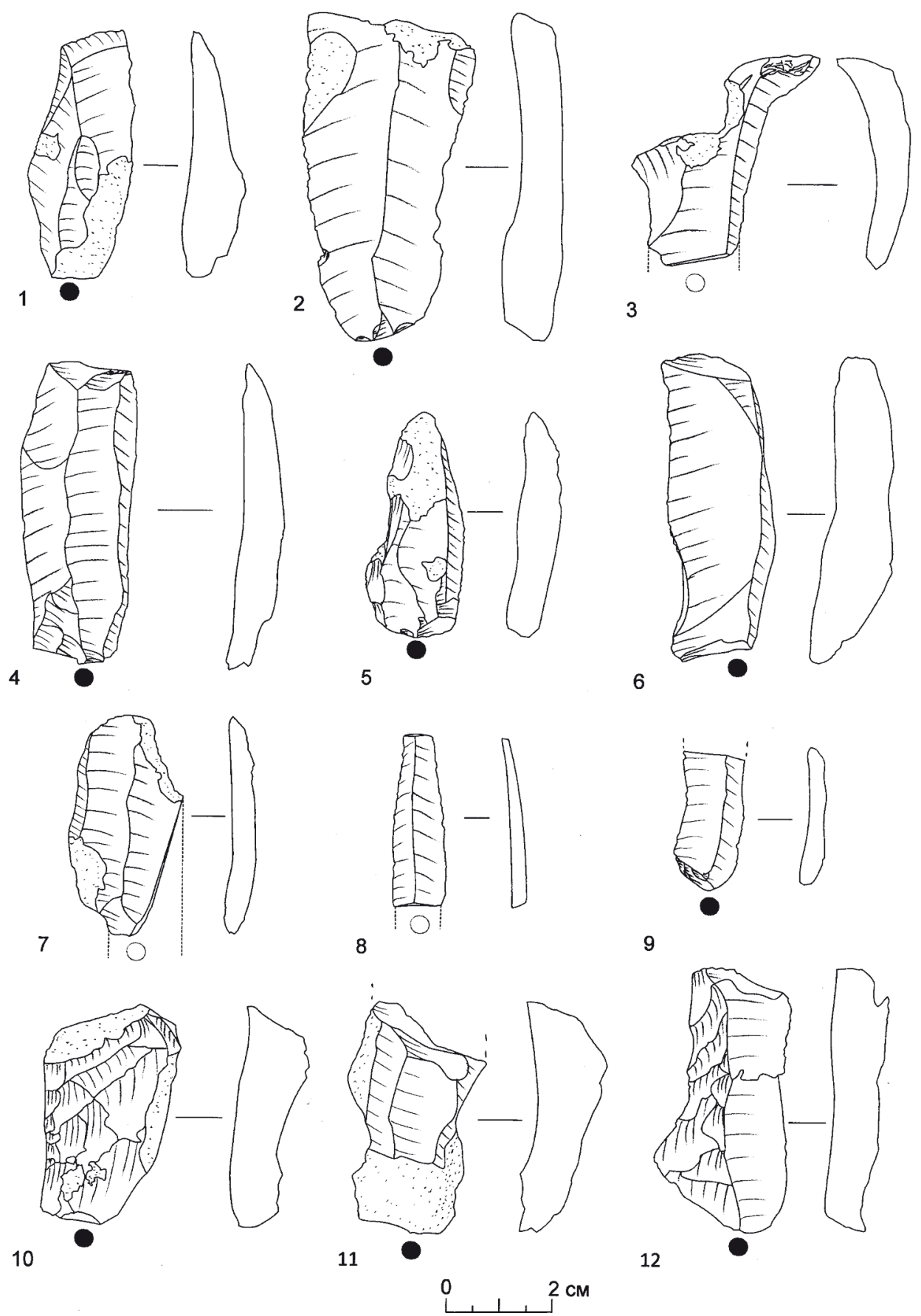

3
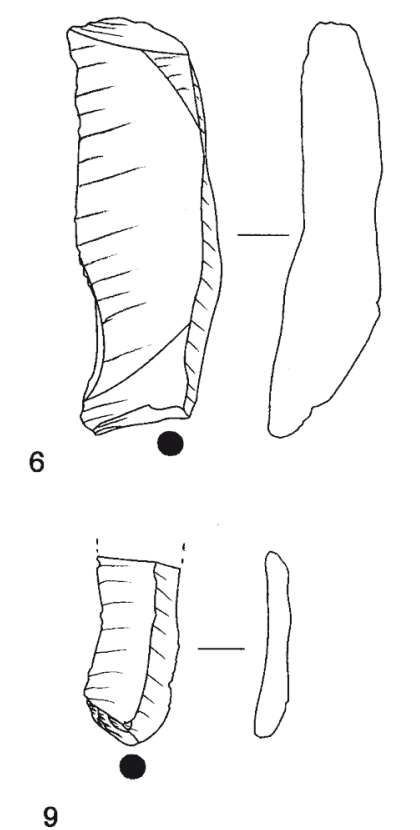

9

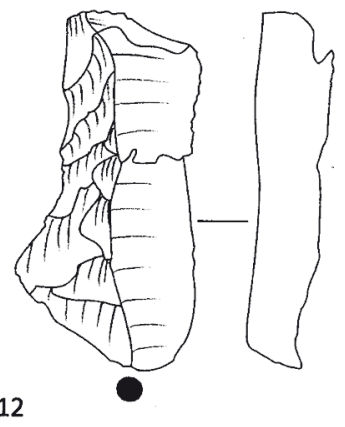

Fig. 8. Țâra II. Blanks and technical flakes (1-12) 
Table 6. Țâra II. Metric parameters of flakes

\begin{tabular}{|c|c|c|c|}
\hline No. & Metric group (length) & Quantity & Percentage \% \\
\hline 1 & $0-10 \mathrm{~mm}$ & 0 & 0.00 \\
\hline 2 & $10-30 \mathrm{~mm}$ & 7 & 19.44 \\
\hline 3 & $30-40 \mathrm{~mm}$ & 11 & 30.56 \\
\hline 4 & over $40 \mathrm{~mm}$ & 18 & 50.00 \\
\hline 5 & Total & 36 & 100.00 \\
\hline
\end{tabular}

Table 7. Țâra II. Metric parameters of blades

\begin{tabular}{|c|c|c|c|c|c|}
\hline Width & Complete & Proximal & Medial & Distal & Total \\
\hline $0-7 \mathrm{~mm}$ & 0 & 0 & 0 & 0 & 0 \\
\hline $7-12 \mathrm{~mm}$ & 1 & 1 & 0 & 1 & 2 \\
\hline $12-20 \mathrm{~mm}$ & 0 & 1 & 0 & 2 & 3 \\
\hline over $20 \mathrm{~mm}$ & 4 & 1 & 0 & 4 & 5 \\
\hline Total & 5 & 3 & 0 & 7 & 15 \\
\hline
\end{tabular}

Table 8. Tools and worked pieces

\begin{tabular}{|c|c|c|}
\hline \multicolumn{1}{|c|}{ Type } & Quantity & Percentage \% \\
\hline Side-scrapers & 2 & $9.5 \%$ \\
\hline End-scrapers & 8 & $38.1 \%$ \\
\hline on an end of a flake & 1 & $4.8 \%$ \\
\hline on an end of a blade & 1 & $4.8 \%$ \\
\hline on technical flakes & 1 & $4.8 \%$ \\
\hline on a side of a flake & 2 & $9.5 \%$ \\
\hline on a side of a technical flake & 1 & $4.8 \%$ \\
\hline fronts & 2 & $9.5 \%$ \\
\hline Flakes with marginal retouch & 6 & $28.6 \%$ \\
\hline Perforators on flakes & 2 & $9.5 \%$ \\
\hline Blades with marginal retouch & 2 & $9.5 \%$ \\
\hline Blades with oblique truncation & 1 & $4.8 \%$ \\
\hline Total & 21 & $100.0 \%$ \\
\hline
\end{tabular}

Thus, the Țâra II collection demonstrated an operative chain oriented towards laminar production. An important feature is the prevalence of cores and by-products of knapping in the collection. Tools are few and atypical. Does this imply that the eight-shaped pit of Țâra II was likely a place where mostly knapping occurred - a "workshop"? The available information makes it unlikely. More likely, the eight-shaped pit was an evacuation zone. 
The absence of small flakes and chips is an important argument contra knapping on-site, considering the disproportions (noted above) in the representation of different technological groups of artefacts. However, knapping oriented toward blade production, followed by the extraction of the produced blades occurred on the site of Țâra II.

\section{DISCUSSION}

In order to develop an interpretation, we need to place Țâra II and Nicolaeuca V into a wider context and compare them to larger collections from other sites: Kamyane-Zavallia, Gura-Camencii VI, Sîngerei I, and Dănceni I (Kiosak 2016; 2017; Larina and Dergachev 2017). The primary composition of each complex indicates important differences (Fig. 9). In some sites, like in Dănceni I, retouched tools outnumber blanks. In others, flakes are very numerous, indicating on-site production. Țâra II stands out by a high percentage of cores.

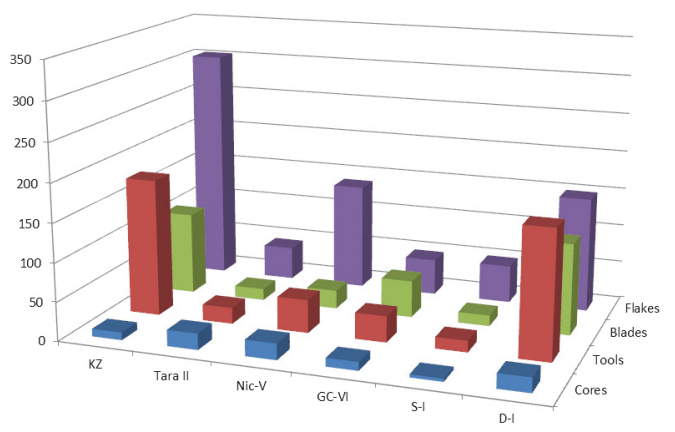

Fig. 9. Comparison of lithic complexes' structures for sites of the easternmost LBK area. KZ - Kamyane-Zavallia ( $n=598$, after Kiosak 2017), Tara II - Țâra II $(n=121)$, Nic-V - Nicolaevca V ( $\mathrm{n}=226$, this work), GC-VI - Gura Camencii VI $(n=140)$, S-I - Sîngerei I $(n=82)$, D-I - Dănceni I $(n=452$, after Larina and Dergachev 2017)

Deeper analysis of the composition of the assemblage reveals several groups of sites. The sites with high indices of retouched tools, Dănceni I and Gura-Camencii VI, stand out. They are clearly "consumer" sites, where lithic implements were widely applied in domestic contexts, while remains of knapping are disproportionally underrepresented considering the amount of retouched blanks. On the other hand, the group of sites in which such remains are well-represented is heterogeneous. Production sites include sites with a bladeoriented industry (like Kamyane-Zavallia) and flake-producing sites (like Nicolaevca V). The Țâra II complex is, in fact, a selection of items resulting from a blade-producing facility, probably with the intention of the further re-utilization of the blades. 
The Late Mesolithic of Moldova is characterised by a fine, regular bladelet knapping technique (Larina et al. 1997; Covalenco 2003; Kitagawa et al. 2018, 195, 196). It existed in two aspects: geometric (Hrebeniki) and non-geometric (Kukrek).

The typical Hrebeniki complexes yielded trapezes of varying shapes (Stanko 1967; Stanko and Kiosak 2010). Although the isosceles types predominate, the scalene specimens are also numerous (Covalenco 2017). A small percentage of microburins is also known (Nuzhnyj 2008, 64). Analogies for the scalene trapezes, which are sometimes known from LBK sites of Moldova and adjacent territories, can be found in the rich, Late Mesolithic assemblages (Stanko 1982). However, they are not the most typical representatives of the Hrebeniki style in any case. Flattened, prismatic, one-sided, unidirectional cores, which are typical for Hrebeniki sites (Stanko and Kiosak 2010, 71), are few or completely absent from Moldovan LBK collections. The cores found in such collections are mostly volumetric prismatic cores with a tendency of development into subconical shapes with reduction. Hrebeniki assemblages are dominated by lamellar components (Stanko and Kiosak 2010, 71), while in LBK complexes, blades are usually more numerous than bladelets.

Kukrek sites yielded a distinctive set of tools and cores (bullet cores, "Abuzova Balka" points, Kukrek inserts, Kukrek burins (Stanko 1967; Stanko et al. 1981; Telegin 1982; Potekhina and Telegin 1995)). Pencil-like (bullet) cores are commonly interpreted as products of the standing pressure technique (Zaliznyak 2005, 78). The end-products of their reduction were microblades (laminar flakes less than $8 \mathrm{~mm}$ wide). None of these features is found in the Moldova LBK assemblages. Microblades are not typical products of serial production for LBK knappers in the region.

Thus, "Mesolithic heritage" is an unlikely explanation for the peculiarities of the assemblages that were described above (Kiosak 2016; 2019).

On the other hand, expedient core technologies are well known from a variety of sedentary societies all over the world (Parry and Kelly 1987). It was suggested that the immediate availability of debris from prior acts of knapping made planned and prepared detachments unnecessary (McCall and Horowitz 2014). Sedentary knappers were able to re-shape and re-utilize the items shaped and applied previously (Parry 2008). The LBK people of Moldova obviously tended to re-use and re-shape by-products of previous knapping. For example, cores re-used as hammerstones are known to any LBK researcher (Kaczanowska 1980; Hofmann et al. 2019).

The lithic industry of the LBK is known to be a complex system, which involves the long-distance transport of raw material and includes finished blades and tools (Mauvilly 1997). The logistic networks corresponded to a mesh of social relations (Zimmermann 1995; Reepmeyer et al. 2011). In some cases, surplus production was described on LBK sites (Burnez-Lanotte and Allard 2003; Allard 2004). These surpluses could be traded further along chains of exchange. Most complexes of the LBK in the region under study were formed both by local production and by the inclusion of some items obtained via 
exchange networks. In this context, the production of blades at Țâra II is not extraordinary. Blades missing from this assemblage could have been supplied to other complexes on the site or traded further on. Meanwhile, the simplistic industry of Nicolaevca $V$ is an anomaly.

A. Zimmermann has demonstrated that LBK sites can be ranged depending on their position in the exchange networks (Zimmermann 1995). There are nodal sites, redistribution sites and consumer sites at the very end of the exchange chain. From this point of view, Nicolaevka V Kleinbau complex is little included in the exchange network. Some objects (like tools on blades) may be products of exchange. However, most artefacts in the complex were obtained by simplistic, expedient, flake-oriented technology, most probably on-site. The "deposit" gives us a unique insight into the organization of knapping at the site. It represents, most probably, the objects selected for further knapping in case of need in a domestic context. The cores and debitage found in the excavation pit could have been produced from objects similar to those found in the deposit in the course of their continued reduction. In other words, a knapper may have selected these pieces (a stone pallet resembling a retouching support, a hammerstone, a flake and a blade, which could be blanks for tools, and 29 objects suitable for further knapping) from some primary knapping place and took them home in anticipation of future needs. They then would likely have used a very simple, expedient technology of blank production, probably via a few blows with a hard stone. Thus, the "deposit" is a selection of objects suitable for further reduction by a knapper, who anticipated his/her need for some pieces of raw material with ample volume, and was not very demanding in regard to the shape of these pieces. It resembles the "caches" for expedient knapping described in some anthropological contexts (McCall 2012; Horowitz and McCall 2019).

Thus, we would expect that the simple, flake-oriented industry of Nicolaevca V should be the result of a domestic mode of production in which a knapper tried to supply the needs of his/her household on his/her own - both obtaining raw material and executing expedient knapping in cases of need.

\section{CONCLUSION}

The structural analysis of lithic collections allows us to define three groups of LBK sites in the territory of modern-day Moldova: 1 ) sites with a flake-oriented industry (Nicolaevca V); 2) sites with abundant evidence for blade production, but which lack blades themselves (Țâra II); 3) sites with an excess of blades and tools on blades (Dănceni I, Gura-Camencii VI).

From the point of view of the social organisation of lithic technology, these differences can be interpreted in the following way: the first group represents remains of domestic, expedient technology, employed by households while attempting to satisfy their own needs. The second and third groups are in systematic relation: the second produced blades, 
yet the assemblages lack them; assemblages of the third group contain a surplus of blades and tools on blades. Thus, the sites of the third group are consumers, most likely obtaining their suplusses of blades via exchange.

\section{Acknowledgements}

The collection of Țâra II was studied thanks to the collaboration of the staff of the Odessa Archaeological Museum (L. Polischuk and M. Lobanova). The collection of Nicolaevca V was analyzed thanks to the hospitality and generosity of Stanislav Țerna, who left this world too early.

\section{References}

Allard P. 2004. L'industrie lithique des populations rubanées du Nord-Est de la France et de la Belgique. Rahden: Verlag Marie Leidorf.

Allard P. and Denis S. 2015. The Circulation of Flint Raw Materials in the Northern France and Belgium during the Early Neolithic. In T. Kerig and S. Shennan (eds), Connecting Networks: characterising contact by measuring lithic exchange in the European Neolithic. Oxford: Archaeopress, 64-73.

Burnez-Lanotte L. and Allard P. 2003. Blade Debitage in the Belgium Linearbandkeramik: the Production at Harduémont «Petit Paradis» (Verlaine). In L. Burnez-Lanotte (ed.), Production and Management of Lithic Materials in the European Linearbandkeramik, actes du $15^{e}$ Congrès de l'UISPP, Liège, septembre 2001. Oxford: Archaeopress, 59-64.

Covalenco S. 2003. Statiunea Mezolitica Bilicenii Vechi 12. Tyragetia 12, 25-36.

Covalenco S. I. 2017. O kulturno-khronologicheskoy pozitsii finalno-mezolithicheskikh pamiatnikov v Pruto-Dnestrovskom mezhdurechie. Stratum Plus 1, 155-171.

Dergachev V. A. and Larina O. V. 2015. Pamiatniki kultury Krish Moldovy (s katalogom). Chişinău: Tipografia Centrala.

Gaskevych D. L. 1997. Vita-Poshtova 2 - nayskhidnishe poselennia z materialamy dunayskoyi neolitychnoyi kultury. Arkheologichni vidkryttia v Ukrayini 1997-1998, 11-13.

Gaskevych D. L. 2003. Kremianyy inventar neolitychnykh kultur Ukrayiny. Kyiv: Diss. of cand. of hist. sc.: 07.00.04.

Gronenborn D. 1997. Silexartefakte der ältestbandkeramischen Kultur. Bonn: Dr. Rudolf Habelt $\mathrm{GmbH}$.

Gronenborn D. 1998. Ältestbankeramische Kultur, La Hoguette, Limburg, and ... What else? - Contemplating the Mesolithic-Neolithic transition in the southern Central Europe. Documenta Praehistorica 25, 189-202.

Hofmann D., Banffy E., Gronenborn D., Whittle A. and Zimmermann A. 2019. Als die Menschen sesshaft wurden: Die Jungsteinzeit in Süd- und Mitteldeutschland. In E. Bánffy, K. P. Hofmann and P. von Rummel (eds), Spuren des Menschen: 800 ooo Jahre Geschichte in Europa. Darmstadt: Theiss in Wissenschaftliche Buchgesellschaft (WBG), 110-133. 
Horowitz R. and McCall G. S. 2019. Lithics in Sedentary Societies: Temes, Methods, and Directions. In R. Horowitz and G. S. McCall (eds), Lithic technologies in sedentary societies. Louisville: University of Colorado Press, 3-34.

Inizan M.-L., Reduron-Ballinger M., Roche H. and Tixier J. 1995. Technologie de la pierre taillée. Meudon: C.R.E.P.

Kaczanowska M. 1980. Steinindustrie der Kultur der Linienbandkeramik. In J. K. Kozłowski and J. Machnik (eds), Problemes de la Neolithisation dans certaines regions de l' Europe. Wrocław: Zakład Narodowy imienia Ossolińskich, Wydawnictwo Polskiej Akademii Nauk, 79-96.

Kiosak D. 2013. Pivdenne Pobuzhzhia - chastyna arealu kultury liniyno-strichkovoyi keramiky. In S. M. Gladun (ed.), IX Mykolayivska oblasna krayeznavcha konferentsia. Istoriografia. Etnografia. Kultura. Novi Doslidzhennia. Mykolaiv: Iryna Gudyma, 75-77.

Kiosak D. 2014. Settlements and Indigenous Populations at the Easternmost Fringe of the Linear Pottery culture. Eurasia Antiqua 20, 117-141.

Kiosak D. 2016. Mesolithic 'Heritage' and Neolithic in Southwest Ukraine. In H. Floss and R. Krauss (eds), Southeast Europe before Neolithisation. Proceedings of the International Workshop within the Collaborative Research Centres sfb 1070 "RessourcenKulturen", Schloss Hohentubingen, $9^{\text {th }}$ of May 2014. Tübingen, 131-147.

Kiosak D. 2017. Kamyane-Zavallia, the eastermost Linear Pottery culture settlement ever excavated. Sprawozdania Archeologiczne 69, 253-170.

Kiosak D. and Salavert A. 2018. Revisiting the chronology of two Neolithic sites in Eastern Europe: new radiocarbon dates from Melnychna Krucha and Kamyane-Zavallia (Southern Buh region, Ukraine). Revista archeologica 14/2, 116-131.

Kiosak D. 2019. The Mesolithic of the north Pontic Region and the transition to the Neolithic. Eurasian Prehistory 15/1-2, 279-292.

Kiosak D., Bruyako I. and Denisjuk V. 2014a. Komplex arkheologicheskikh pamiatnikov KamianeZavallia v Srednem Pobuzhie: raboty 2011-2012. Tyragetia 8 (23/1), 73-88.

Kiosak D., Kotova N., Tinner W., Szidat S., Nielsen E., Brugger S., de Capitani A., Gobet E. and Makhortykh S. 2020. The last hunter-gatherers and early farmers of the middle Southern Buh river valley (Central Ukraine) in VIII-V mill. BC. Radiocarbon 63/1, 121-137.

Kiosak D., Saile T., Dębiec M. and Posselt M. 2014b. Rozkopky poselennia kultury liniyno-strichkovoyi keramiky Kamyane-Zavallia 2013 roku. In D. Kozak (ed.), Arkheologichni doslidzhennia v Ukrayini 2013 roku. Kyiv: IA NAS Ukraine, 202-203.

Kitagawa K., Julien M.-A., Krotova O., Bessudnov A., Sablin M. V., Kiosak D., Leonova N., Plohenko B. and Patou-Mathis M. 2018. Glacial and post-glacial adaptations of hunter-gatherers: Investigating the late Upper Paleolithic and Mesolithic subsistence strategies in the southern steppe of Eastern Europe. Quaternary International 465, 192-209.

Korobkova G. F. 1987. Khoziaystvennye kompleksy rannikh zemledelchesko-skotovodcheskikh obschestv yuga SSSR. Moscow: Nauka.

Kozłowski J. 1989. The neolithization of South-east Europe: an alternative approach. Varia Archaeologica Hungarica 2, 131-148. 
Larina O., Wechler K.-P., Dergačev V. A., Covalenco S. and Bikbaev V. M. 1997. Novye polevye issledovaniya pamiatnikov mezolita i neolita Moldovy. In V. Dergaciov (ed.), Vestigii arheologice din Moldova. Chişinău: Tipografia Academiei de Ştiințe RM, 62-110.

Larina O. V. 1999. Kultura lineyno-lentochnoy keramiky Pruto-Dnestrovskogo regiona. Stratum Plus 2, 10-140.

Larina O. V. and Dergaciov V. A. 2017. Pamiatniki kultury lineyno-lentochnoy keramiki Respubliki Moldova (svod istochnikov). Chişinău: Academy of Sciences of Moldova, Cultural Heritage Institute.

Lüning J. 1982. Forschungen zur bandkeramischen Besiedlung der Aldenhovener Platte im Rheinland In J. Pavúk (ed.), Siedlungen der Kultur mit Linearkeramik in Europa. Nove Vozokany 1720 November 1981. Nitra: Archäeologisches Institut der Slowakischen Akademie der Wissenschaften, 125-156.

Man'ko V. O. and Telizhenko S. 2016. Problemy pokhodzhennia kultury liniyno-strichkovoyi keramiky na zakhodi Ukrainy. Naukovi studiyi. Istoryko-kraeznavchyi muzey m. Vynnyky, Instytut arkheologii Zheshivskogo universytetu 9, 3-24.

Marchand G. 1999. La néolithisation de l'ouest de la France: caractérisation des industries lithiques (= British Archaeological Reports. International Series 748). Oxford: BAR Publishing.

Markevich V. I. 1974. Bugo-Dnestrovskaya kultura na territorii Moldavii. Chişinău: Ştiința.

Mateiciucova I. 2008. Talking stones: the chipped stone industry in Lower Austria and Moravia and the beginnings of the Neolithic in Central Europe (LBK), 5700-490o BC. Brno: Masarykova Univerzita.

Mauvilly M. 1997. L’industrie lithique de la culture à céramique linéaire de Haute et de Basse Alsace: état des recherches et bilan provisoire. In C. Jeunesse (ed.), Le Néolithique Danubien et ses Marges entre Rhin et Seine. Actes du XXII ${ }^{\text {èe }}$ colloque interrégional sur le Néolithique, Strasbourg, 1995. Zimmersheim: Cahiers de l'Association pour la promotion de la recherche archéologique en Alsace, 327-358.

McCall G. S. 2012. Ethnoarchaeology and the Organization of Lithic Technology. Journal of Archaeological Research 20/2, 157-203. DOI: 10.1007/s10814-011-9056-z

McCall G. S. and Horowitz R. 2014. Comparing Forager and Pastoralist Technological Organization in the Central Namib Desert, Western Namibia. In M. J. Shott (ed.), Works in Stone: Contemporary Perspectives on Lithic Analysis, 2014. Salt Lake City: University of Utah Press, 63-77.

Nikitin A. G., Stadler P., Kotova N., Teschler-Nicola M., Price T. D., Hoover J., Kennett D. J., Lazaridis I., Rohland N., Lipson M. and Reich D. 2019. Interactions between earliest Linearbandkeramik farmers and central European hunter gatherers at the dawn of European Neolithization. Scientific Reports 9/1, 19544. DOI: 10.1038/s41598-019-56029-2.

Nowak M. 2007. Middle and Late Holocene hunter-gatherers in East Central Europe: changing paradigms of the 'non-Neolithic' way of life. Documenta Praehistorica 34, 89-103. DOI: 10.4312/ dp.34.7.

Nowak M. 2019. The first vs. second stage of neolithisation in Polish territories (to say nothing of the third?). Documenta Praehistorica 46, 102-127. DOI: 10.4312/dp.46.7. 
Nuzhnyj D. 2008. Rozvytok mikrolitychnoyi tekhniky v kamianomu vitsi: udoskonalennia zbroyi pervisnykh myslyvtsiv. Kyiv: Naukova dumka.

Parry W. A. 2008. Expedient Lithic Technology from Oldowan to Ethnographic: Some Reflections, Twenty Years Later, Paper presented at Society for Anerican Archaeology meeting, 2008.

Parry W. A. and Kelly R. L. 1987. Expedient core technology and sedentism. In J. K. Johnson and C. A. Morrow (eds), The organization of core technology. Colorado: Westview Press, 285-304.

Passek T. S. and Chernysh E. K. 1963. Pamiatniki kultury lineino-lentochnoy keramiki na territorii SSSR. Svod arkheologicheskikh istochnikov B 1-2, 5-42.

Păunescu A. 1970. Evoluția uneltelor şi armelor de piatră cioplită descoperite pe teritoriul Romậniei. Bucureşti: Editura Academiei Republicii Socialiste Romậnia.

Pawlikowski M. 1992. The Origin of Lithic Raw Materials. In J. K. Kozłowski, H. Laville and B. Ginter (eds), Temnata Cave. Kraków: Jagellonian University Press, 241-286.

Petrougne V. F. 1971. O geologicheskoy pozitsii i obrabotannom kremne mezoliticheskoy stoyanki Belolesie. Materialy po arkheologii Severnogo Prichernomoriya 7, 110-117.

Petrougne V. F. 1995. Petrographical-lithological characteristics of stone materials from the late-Tripolye cemeteries of Sofievka-type. Baltic-Pontic Studies 3, 190-199.

Potekhina I. and Telegin D. 1995. On the Dating of the Ukrainian Mesolithic-Neolithic Transition. Current Anthropology 36/5, 823-826.

Reepmeyer C., Claßen E. and Zimmermann A. 2011. 'Bandkeramik' stone tool production and social network analysis: a case study. In B. Marwick and A. Mackay (eds), Keeping your Edge: Recent Approaches to the Organisation of Stone Artefact Technology. Oxford: Archaeopress, 85-96.

Saile T. 2020. On the Bandkeramik to the east of the Vistula River: At the limits of the possible. Quaternary international 560-561, 208-227. DOI: 10.1016/j.quaint.2020.04.036.

Saile T., Dębiec M., Posselt M., Țerna S. and Kiosak D. 2016. Zur Bandkeramik zwischen Pruth und Südlichem Bug. Praehistorische Zeitschrift 91/1, 1-15. DOI: 10.1515/pz-2016-0001.

Stanko V. N. 1967. Mezolit Severo-Zapadnogo Prichernomoriya. Kyiv: Diss. for candidate of historical science, Institute of Archaeology of NAS Ukraine.

Stanko V. N. 1982. Mirnoe. Problema mezolita stepey Severnogo Prichernomoria. Kyiv: Naukova Dumka. 
